\title{
Asupan Zat Besi, Asam Folat, dan Vitamin C pada Remaja Putri di Daerah Jatinangor
}

\author{
Puspa Sari ${ }^{1}$, Dini Izmi Azizah ${ }^{2}$, Lani Gumilang ${ }^{3}$, Raden Tina Dewi Judistiani ${ }^{4}$, \\ Aryati Mandiri ${ }^{5}$ \\ Departemen Ilmu Kesehatan Masyarakat, Fakultas Kedokteran, Universitas Padjadjaran ${ }^{1,3,4,5}$ \\ Program Diploma IV Kebidanan, Fakultas Kedokteran, Universitas Padjadjaran ${ }^{2}$ \\ dini.izmi.azizah@gmail.com²
}

\begin{abstract}
Diajukan 31 Mei 2019 Diperbaiki 26 November 2019 Diterima 27 November 2019
\section{ABSTRAK}

Latar Belakang: Masa remaja merupakan masa yang rentan terjadinya anemia dikarenakan cenderung mengalami kekurangan asupan gizi yang dibutuhkan oleh tubuh terutama zat besi, asam folat, dan vitamin C. Tujuan penelitian ini adalah mengetahui rerata dan proporsi kecukupan asupan zat besi, asam folat, dan vitamin $C$ pada remaja putri di Kecamatan Jatinangor.

Metode: Penelitian deskriptif dengan pendekatan potong lintang pada remaja putri usia 10-19 tahun periode Juni-Agustus 2018. Data asupan gizi diperoleh melalui 3 day-food record dan dilakukan follow up melalui Whatsapp Group, kemudian dilakukan konversi ukuran makanan dari bentuk Ukuran Rumah Tangga menjadi gram melalui buku foto makanan. Setelah itu, dimasukkan kedalam aplikasi nutrisurvey untuk dihitung kandungan asupan gizi dan dirata-ratakan serta dibandingkan dengan Angka Kecukupan Gizi yang

direkomendasikan oleh Permenkes.

Hasil: Penelitian ini menunjukkan bahwa rerata asupan zat besi sebesar 10,67 mg/hari, responden yang tidak memenuhi kecukupan zat besi sebesar 93,6\% (88 orang). Rerata asupan asam folat sebesar $180,67 \mu \mathrm{g} / \mathrm{hari}$, sebagian besar responden tidak memenuhi kecukupan asam folat mencapai 94,7\% (89 orang). Rerata asupan vitamin C sebesar 29,71 $\mathrm{mg} /$ hari dimana sebagian besar responden tidak memenuhi kecukupan vitamin $C$ yaitu sebesar $67 \%$ (63 orang).

Kesimpulan: Rerata asupan zat besi, asam folat, dan vitamin $C$ remaja putri dibawah standar AKG dan tidak memenuhi AKG yang direkomendasikan. Hal ini dikarenakan jenis bahan makanan yang dikonsumsi remaja tidak bervariasi. Untuk memperbaiki asupan gizi dan status gizi remaja perlu upaya peningkatan pengetahuan gizi, salah satunya melalui pendidikan gizi.
\end{abstract}

Kata Kunci: asam folat; asupan; remaja; vitamin c; zat besi

\section{ABSTRACT}

Background: Adolescence was a vulnerable period of anemia because in this age, they tended to experience a nutritional deficiency, especially iron, folic acid and vitamin $C$. The purpose of this study was to determine the average and proportion of adequate intake of iron, folic acid and vitamin Cofteenage girls in Jatinangor.

Method: This study used descriptive research method with a cross-sectional approach on girls aged 10-19 years on June-August 2018. Data on nutritional intake were obtained through 3 day-food records and followed up through WhatsApp Group, and then conversion of food sizes from Household Size to grams was done through food photo book. After that, it was analyzed using Nutrisurvey application to calculate the content of nutritional intake and its average and compared to the Recommended Dietary Allowance (RDA) by Ministry of Health

\section{Regulation.}

Results: This study showed that the average iron intake was $10.67 \mathrm{mg} /$ day, which respondents who did not meet iron adequacy were $93.6 \%$ (88 girls). The average of folic acid intake was $180.67 \mu \mathrm{g} /$ day most of respondents did not meet the adequacy of folic acid intake reaching out $94.7 \%$ (89 girls). The average of vitamin C intake was 29.71 mg/day in which most of respondents did not meet the adequacy of vitamin C intake reaching out $67 \%$ (63 girls). Conclusion: The average iron intake, folic acid and vitamin $C$ of the respondents were under the $R D A$ standard and did not meet the recommended RDA. This is caused by food type consumed by respondents was not varied. To improve nutrition intake and nutritional status of adolescents, need to be done to improve nutrition knowledge, one of which was through nutrition education.

Keywords: folic acid; intake; adolescents; vitamin C; iron 


\section{PENDAHULUAN}

Menurut World Health Organization, remaja merupakan rentang kehidupan yang berusia antara 10-19 tahun (WHO, 2018a). Di negara-negara Asia Tenggara populasi remaja sekitar 20\%, dengan usia antara 10-19 tahun. Periode remaja merupakan periode yang sangat penting, dikarenakan terjadi perubahan fisik, psikologis, dan perilaku yang besar. Periode ini merupakan masa transisi dari masa anak-anak menuju masa remaja, ditandai dengan banyak perubahan yang memengaruhi kebutuhan gizi. Kebutuhan gizi yang tinggi pada masa remaja dikarenakan oleh peningkatan pertumbuhan dan aktivitas fisik (Kaur \& Sangha, 2016). Hal ini diperlukan agar tercapai potensi pertumbuhan secara maksimal. Gizi yang baik sangat penting untuk mencegah gangguan nutrisi dan mencegah timbulnya penyakit dikemudian hari(IDAI, 2013).

Kebutuhan gizi yang meningkat selama masa remaja salah satunya adalah zat besi. Hal ini dikarenakan pertumbuhan yang cepat dengan peningkatan dalam massa tubuh tanpa lemak, volume darah, dan massa eritrosit (sel darah merah) yang meningkatkan kebutuhan zat besi untuk mioglobin pada otot dan hemoglobin dalam darah. Pada anak perempuan, percepatan pertumbuhan tidak begitu besar, namun biasanya terjadi menstruasi yang dimulai sekitar satu tahun setelah puncak pertumbuhan dan beberapa zat besi hilang selama menstruasi (Tayel \& Ezzat, 2015). Jika hal ini tidak diimbangi dengan asupan zat besi yang memadai dapat menyebabkan terjadinya anemia.

Kekurangan zat besi dianggap sebagai penyebab paling umum kejadian anemia di seluruh dunia, walaupun defisiensi asam folat, vitamin B12 dan vitamin A, dan kelainan bawaaan semuanya dapat menyebabkan anemia. Anemia merupakan kondisi dimana jumlah eritrosit atau kapasitas pembawa oksigen tidak mencukupi kebutuhan fisiologis sehingga akan mengganggu pembentukan eritrosit. Terganggunya pembentukan eritrosit dapat dikarenakan kurangnya mengonsumsi makanan yang mengandung zat gizi terutama zat-zat gizi penting seperti zat besi, asam folat, vitamin $\mathrm{C}$, dan zat gizi penting lainnya $(\mathrm{WHO}$ 2018). Kekurangan zat gizi dapat menyebabkan anemia dikarenakan tidak memadainya zat gizi yang dibutuhkan untuk memproduksi dan mensintesis eritrosit Asupan zat gizi yang rendah zat besi merupakan penyebab utama terjadinya anemia, karena sel darah merah berperan penting dalam menyalurkan oksigen (SPRING, 2017).

Tujuan penelitian ini untuk mengetahui rerata dan proporsi kecukupan ssupan zat besi, asam folat, dan vitamin C pada remaja putri di Kecamatan Jatinangor.

\section{METODE}

Penelitian ini menggunakan metode deskriptif dengan pendekatan potong lintang pada remaja putri usia 10-19 tahun yang berjumlah 94 orang dan dilaksanakan bulan Juni-Agustus 2018 di Kecamatan Jatinangor. Sampel penelitian ini menggunakan teknik purposive sampling. Pengambilan sampel ini dipilih berdasarkan kriteria inklusi yaitu remaja putri usia 10-19 tahun yang belum pernah hamil dan menikah. Instrumen yang digunakan adalah lembar estimated food record dan jenis data yang digunakan adalah data primer. Pengambilan data diperoleh melalui 3 day-food record yaitu dengan cara mencatat setiap makanan yang dikonsumsi selama berturut turut, $3 \times 24$ jam.

Dalam pencatatan makanan, remaja dilakukan follow up melalui Whatsapp Group selama 3 hari. Setelah itu, untuk memastikan ukuran makanan yang dikonsumsi digunakan buku foto makanan.

Setelah dilakukan pengumpulan data, dilakukan analisis dengan cara mengonversi ukuran makanan yang dikonsumsi remaja dari bentuk porsi (Ukuran Rumah Tangga) kedalam bentuk gram dengan menggunakan buku foto makanan. Hasil analisis dimasukkan kedalam aplikasi nutrisurvey untuk dihitung kandungan zat besi, folat dan vitamin C pada setiap 
makanan yang dikonsumsi oleh setiap remaja, kemudian diakumulasikan dan dirata-ratakan selama 3 hari. Kemudian hasil dari rata-rata dibandingkan dengan Angka Kecukupan Gizi (AKG) remaja putri usia 10-19 tahun menurut Peraturan Menteri Kesehatan Republik Indonesia Tahun 2013 Mengenai Angka Kecukupan Gizi yang dianjurkan Bagi Bangsa Indonesia. Kemudian untuk menentukan proporsi kecukupan asupan zat besi, asam folat, dan vitamin $C$ dikategorikan menjadi terpenuhi $(\geq A K G)$ dan tidak terpenuhi $(<A K G)$.

\section{HASIL PENELITIAN}

Hasil penelitian ini didapatkan rerata asupan zat besi sebesar 10,67 mg/hari, asam folat sebesar 180,67 $\mu \mathrm{g} / \mathrm{hari}$, dan vitamin C sebesar 29,71 mg/hari. Rerata tersebut dibawah standar Angka Kecukupan Gizi yang direkomendasikan oleh Peraturan Menteri Kesehatan.

Tabel 1 Rerata Asupan Zat Besi, Asam Folat, dan Vitamin C Remaja Putri di Kecamatan Jatinangor

\begin{tabular}{cc}
\hline Asupan Gizi & $\begin{array}{c}\text { Rerata Asupan } \\
\text { selama 3 hari }\end{array}$ \\
\hline Zat Besi & $10,67 \mathrm{mg}$ \\
Asam Folat & $180,67 \mu \mathrm{g}$ \\
Vitamin C & $29,71 \mathrm{mg}$ \\
\hline
\end{tabular}

Rerata asupan zat besi remaja putri usia 10-12 tahun hanya memenuhi 50,2\% yaitu sebesar 10,06 mg/hari dan usia 13-19 tahun hanya memenuhi $46,5 \%$ yaitu sebesar 12,08 $\mathrm{mg} /$ hari. Rerata tersebut dibawah standar AKG yang direkomendasikan Permenkes yaitu 20 $\mathrm{mg} /$ hari untuk perempuan usia 10-12 tahun dan $26 \mathrm{mg} /$ hari untuk perempuan usia 13-19 tahun. Demikian pula didapatkan hasil rerata asupan asam folat remaja putri usia 10-19 tahun hanya memenuhi 45,2\% yaitu sebesar 180,67 $\mu \mathrm{g} /$ hari dari AKG yang direkomendasikan yaitu $400 \mu \mathrm{g} /$ hari.

Adapun rerata asupan vitamin $C$ remaja putri usia 10-12 tahun memenuhi 83,3\% yaitu sebesar 41,69 mg/hari, usia 13-15 tahun memenuhi $65,5 \%$ yaitu sebesar $42,56 \mathrm{mg} /$ hari, dan usia 16-19 tahun memenuhi 50,\% yaitu reratanya sebesar 37,58 $\mathrm{mg} /$ hari dari AKG asupan vitamin C yang direkomendasikan oleh Permenkes. Rerata asupan tersebut dibawah standar AKG yaitu $50 \mathrm{mg} /$ hari bagi perempuan usia 10-12 tahun, $65 \mathrm{mg} /$ hari bagi usia 13-15 tahun, dan $75 \mathrm{mg} /$ hari bagi usia 16-19 tahun.

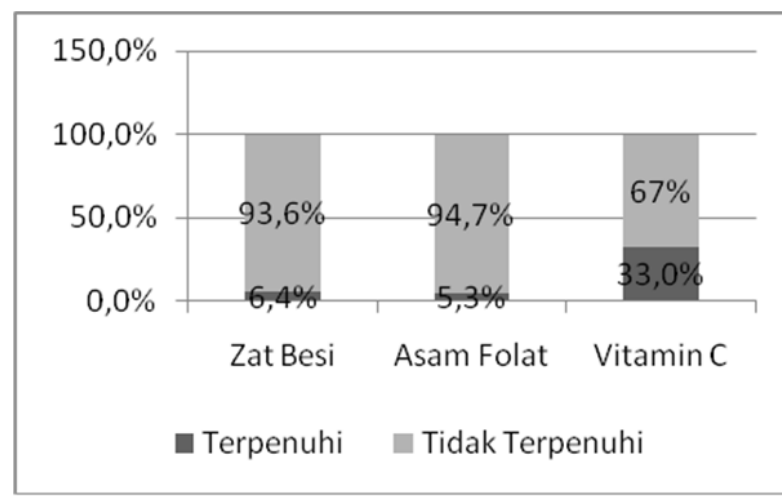

Grafik 1 Proporsi Kecukupan Asupan Zat Besi, Asam Folat, da Vitamin C Remaja Putri di Kecamatan Jatinangor

Dari grafik tersebut diperoleh proporsi kecukupan asupan zat besi yang memenuhi standar AKG perempuan usia 10-19 tahun sebesar $6,4 \%$ (6 orang) dan 93,6\% (88 orang) tidak memenuhi asupan zat besi. Responden yang memenuhi asupan asam folat sesuai AKG yang direkomendasikan sebesar 5,3\% (5 orang) dan $94,7 \%$ (89 orang) tidak memenuhi asupan asam folat, sedangkan responden yang memenuhi asupan vitamin $C$ sesuai $A K G$ yang direkomendasikan sebesar 33\% (31 orang) dan responden yang tidak memenuhi asupan vitamin C sebesar 67\% (63 orang).

\section{PEMBAHASAN}

Hasil penelitian ini menunjukkan rerata asupan zat besi pada remaja putri tergolong rendah dari Angka Kecukupan Gizi yang rekomendasikan yaitu hanya sebesar 10,06 mg/hari pada usia 10-12 tahun dan 12,08 mg/hari pada usia 3-19 tahun. Rerata tersebut dibawah standar Angka Kecukupan Gizi perempuan usia 10-12 tahun menurut Peraturan Menteri Kesehatan (Permenkes) yaitu $20 \mathrm{mg} /$ hari dan $20 \mathrm{mg} /$ haribagi usia 13-19 tahun. Hal ini sesuai dengan penelitian Alfishar (2017), menujukkan hasil rerata asupan zat besi remaja putri berusia 17-20 tahun masih belum 
terpenuhi yaitu hanya sebesar 7,8 $\mathrm{mg}$ /hari (Akib \& Sumarmi, 2017).

Demikian pula dalam penelitian $\underline{\text { Akram }}$ (2018) yang dilakukan di Iran pada remaja tingkat sekolah menengah atas yang berjumlah 800 responden menunjukkan hasil bahwa asupan zat besi pada remaja lebih rendah dibandingkan jumlah makanan harian yang dikomendasikan yaitu hanya sebesar 9,5 mg/hari (Kooshki, Mohammadi, \& Rivandi, 2018). Penelitian ini juga menyebutkan bahwa asupan zat besi pada remaja usia 16-19 tahun dikatakan rendah dengan rerata asupan zat besi sebesar $8 \mathrm{mg} / \mathrm{hari}$.

Pada penelitian ini, didapatkan bahwa responden yang tidak memenuhi kecukupan zat besi mencapai 93,6\% (88 orang) dan yang memenuhi zat besi sebesar $6,4 \%$ (6 orang). Jenis makanan yang dikonsumsi oleh salah satu responden dengan asupan zat besi yang tergolong terpenuhi lebih beragam dan lebih banyak mengandung sumber zat besi hewani maupun nabati seperti daging ayam, telur, tahu, tempe bacem, sayur sop, tumis kangkung, tumis sawi, dan jeruk, sedangkan jenis makanan yang dikonsumsi oleh salah satu responden yang tergolong tidak terpenuhi kurang beragam dan hanya sedikit mengandung sumber zat besi yaitu sayur sop, telur, dan taoge. Hal tersebut dapat menjadi faktor penyebab tidak terpenuhinya asupan zat besi dikarenakan keragaman konsumsi makanan berperan penting dalam pembentukan eritrosit dan membantu meningkatkan penyerapan zat besi didalam tubuh.

Kekurangan zat gizi seperti zat besi dapat menyebabkan terjadinya anemia dikarenakan tidak memadainya zat gizi yang dibutuhkan untuk memproduksi dan mensintesis eritrosit. Salah satunya yaitu menyebabkan terjadinya anemia defisiensi besi yang ditandai gejala klinis seperti konjungtiva pucat, sesak napas, pusing, dan lesu. Anemia defisiensi besi ditandai sintesis hemoglobin yang tidak sempurna karena defisisensi besi yang signifikan, sehingga mengakibatkan berkurangnya kapasitas eritrosit yang menyalurkan oksigen ke sel-sel tubuh dan jaringan (Paracha et al., 2016).

Rerata asupan asam folat pada remaja putri sebanyak 180,96 $\mu \mathrm{g} /$ hari, angka tersebut dibawah standar AKG asupan asam folat perempuan usia 10-19 sebesar $400 \mu \mathrm{g} / \mathrm{hari}$. Begitu pula hasil penelitian Akram (2018) di Iran menunjukkan hasil bahwa asupan asam folat remaja lebih rendah dibandingkan jumlah makanan harian yang direkomendasikan yaitu hanya sebesar 284,2 $\mu \mathrm{g} /$ hari (Kooshki et al., 2018). Hasil dari penelitian ini didapatkan responden yang tidak memenuhi asupan asam folat sebanyak $94,7 \%$ (89 orang) dan responden yang memenuhi sebesar 5,3\% (5 orang).

Jenis makanan yang dikonsumsi oleh salah satu responden yang asupan asam folatnya terpenuhi lebih beragam dibandingkan dengan responden yang tidak memenuhi asupan folat.

Rerata asupan vitamin C pada remaja putri usia 10-12 tahun sebesar 41,69 mg/hari, usia 13-15 tahun sebesar $42,56 \mathrm{mg} / \mathrm{hari}$, dan usia 16-19 tahun sebesar 37,58 mg/hari, sedangkan AKG asupan vitamin C menurut Permenkes mencapai $50 \mathrm{mg} / \mathrm{hari}$ untuk perempuan usia 10-13 tahun, $65 \mathrm{mg} /$ hari untuk perempuan usia 14-15 tahun, dan $75 \mathrm{mg} /$ hari untuk perempuan usia 16-19 tahun. Hasil penelitian ini sejalan dengan Alfishar (2017) yakni didapatkan bahwa remaja usia 17-20 tahun memiliki asupan vitamin $C$ yang rendah dengan rerata sebesar 12,5 mg/hari (Akib \& Sumarmi, 2017). Selain itu, penelitian Akram (2018) di Iran juga menyebutkan bahwa rerata asupan vitamin C pada remaja tingkat menengah atas lebih rendah dibandingkan jumlah makanan harian yang dikomendasikan yaitu hanya sebesar 30,5 $\mathrm{mg} /$ hari(Kooshki et al., 2018).

Dari hasil penelitian ini didapatkan sebagian besar responden tidak memenuhi kecukupan vitamin C yaitu mencapai $67 \% \quad$ (63 orang) dan responden yang memenuhi kecukupan vitamin C sebesar 33\% yaitu sebanyak 31 orang.

Berdasarkan penelitian ini diperoleh 
hasil jenis makanan yang dikonsumsi oleh salah satu responden yang memenuhi asupan vitamin $\mathrm{C}$ lebih bervariasi dan lebih banyak mengandung sumber vitamin $C$ seperti jus jeruk, mangga, singkong, dan salak, sedangkan jenis makanan yang dikonsumsi oleh salah satu responden dengan nilai asupan vitamin $\mathrm{C}$ rendah, kurang bervariasi dan hanya sedikit mengandung sumber vitamin $C$ seperti sayur labu dan dan sayur sop.

Salah satu penyebab dari kurangnya asupan zat besi, asam folat, dan vitamin $C$ pada sebagian besar remaja adalah pola makan yang tidak baik contohnya seperti makan tidak teratur dan jenis bahan makanan yang tidak bervariasi. Pola makan memberikan gambaran mengenai frekuensi, macam dan model bahan makanan yang dikonsumsi tiap hari. Pola makan yang direkomendasikan bagi remaja yaitu mengonsumsi makanan bergizi seimbang, terdiri atas sumber zat pengatur seperti buah-buahan dan sayuran, sumber tenaga seperti beras, roti, umbi-umbian, dan tepung-tepungan. Selain itu terdiri atas zat pembangun yang bersumber nabati maupun hewani. Sumber nabati seperti tahu, tempe, dan kacang-kacangan serta sumber hewani seperti telur, ikan, susu, daging ayam maupun sapi (Suryani, Hafiani, \& Junita, 2017).

Pada masa remaja cenderung terjadi peningkatan asupan makanan siap saji yang mengandung tinggi lemak dan tinggi kalori namun rendah zat besi, asam folat, dan vitamin C. Makanan berperan dalam memelihara kesehatan tubuh melalui manfaat kandungan zat gizi didalamnya. Kualitas makanan yang baik dan jumlah makanan yang terpenuhi akan memengaruhi kesehatan tubuh yang optimal.

Padatnya aktivitas fisik yang dilakukan remaja dapat pula mengakibatkan kekurangan asupan zat gizi. Remaja memiliki banyak kegiatan, seperti sekolah pagi sampai siang, diteruskan kegiatan ekstrakurikuler hingga sore, dan belum lagi jika ada kegiatan tambahan. Semua aktivitas tersebut membuat mereka tidak sempat untuk makan, apalagi memikirkan bagaimana komposisi dan kandungan zat gizi yang seharusnya dikonsumsi. Hal demikian mengakibatkan asupan gizi remaja menjadi tidak tidak terpenuhi.

Penyebab lainnya tidak terpenuhinya asupan gizi pada remaja dikarenakan kurangnya pengetahuan gizi sehingga menimbulkan terjadinya kesalahan dalam memilih makanan yang dikonsumsi. Pola makan remaja yang kurang tepat berawal dari pola makan keluarga yang kurang tepat. Mulai dari jadwal makan yang tidak teratur dan mengosumsi makanan seadanya tanpa mengetahui kebutuhan zat gizi yang harus terpenuhi. Jika pola tersebut sudah tertanam sejak kecil maka akan berlanjut sampai usia remaja sehingga dapat berdampak terhadap kesehatan pada periode kehidupan selanjutnya.

Kekurangan asupan gizi seperti asam folat, vitamin C, dan terutama zat besi akan berdampak terjadinya anemia terutama anemia gizi pada masa remaja dikarenakan di awal masa remaja cenderung mengalami kekurangan zat besi (World Health Organization, 2011). Berdasarkan penelitian Alfishar (2017), remaja dengan asupan zat besi kurang lebih banyak mengalami anemia, yaitu sekitar $72 \%$ dibandingkan dengan tidak mengalami anemia (Akib \& Sumarmi, 2017). Demikian pula remaja dengan tingkat asupan vitamin C kurang lebih banyak mengalami anemia yaitu $73,3 \%$ dibandingkan tidak menderita anemia.

Anemia pada remaja memiliki dampak negatif yang signifikan seperti mempengaruhi pertumbuhan remaja putri, ingatan dan kinerja di sekolah (prestasi, serta kehadiran di sekolah). Hal tersebut dikarenakan anemia yang disebabkan oleh defisiensi besi berpengaruh pada fungsi sistem saraf otak dan sistem saraf pusat sehingga dapat mengakibatkan terhambatnya fungsi kognitif remaja. Remaja yang mengalami anemia tidak akan memiliki motivasi belajar yang tinggi karena akan sulit untuk berkonsentrasi karena terjadi penurunan daya tahan tubuh dan 
kemampuan belajar akibat dari rendahnya kadar hemoglobin dalam tubuh (Chen et al., 2013).

Penelitian Chen (2013) pada remaja usia 10-18 tahun, menunjukkan hasil bahwa remaja dengan status anemia defisiensi besi secara signifikan berkaitan dengan meningkatnya risiko 2,89 lebih tinggi terjadinya gangguan depresi unipolar dikarenakan konsentrasi feritin serum yang rendah secara signifikan berhubungan dengan gejala depresi (Chen et al., 2013). Selain itu, anemia defisiensi besi pada remaja meningkatkan 3,71 lebih tinggi terjadinya risiko gangguan kecemasan, dikarenakan tubuh kekurangan komponen penting sehingga dapat menimbulkan gangguan perkembangan otak. Zat besi dianggap sebagai suatu elemen nutrisi yang penting yang berhubungan dengan kognitif dan fungsi sosio-emosional. Jika anemia terjadi pada remaja putri yang akan hamil dapat meningkatkan risiko perinatal, meningkatkan kejadian Berat Badan Lahir Rendah (BBLR), peningkatan Angka Kematian Bayi (AKB) dan Angka Kematian Ibu (AKI).

Sebagai upaya memperbaiki asupan gizi dan status gizi remaja antara lain perlu meningkatkan pengetahuan gizi, salah satunya melalui pendidikan gizi. Pendidikan gizi menghasilkan peningkatan kesadaran, pengetahuan, dan perubahan perilaku untuk mencapai keadaan gizi dan kesehatan yang optimal. Pendidikan ini diharapkan menjadi solusi untuk meningkatkan derajat kesehatan remaja. Dalam pelaksanaan pendidikan gizi dibutuhkan kerjasama dari berbagai pihak seperti institusi pendidikan maupun kesehatan. Pendidikan gizi di sekolah dapat diberikan oleh guru yang telah mendapat pelatihan pendidikan gizi atau diberikan langsung petugas gizi. (Nurmasyita, Widjanarko, \& Margawati, 2016).

\section{PENUTUP}

Rerata asupan zat besi, asam folat, dan vitamin $C$ remaja putri dibawah standar AKG dan tidak memenuhi AKG yang direkomendasikan. Selain itu, sebagian besar remaja putri tidak memenuhi prosporsi kecukupan asupan zat besi, asam folat, dan vitamin C. Hal ini dikarenakan jenis bahan makanan yang dikonsumsi remaja tidak bervariasi. Untuk memperbaiki asupan gizi dan status gizi remaja antara lain perlu upaya peningkatan pengetahuan gizi, salah satunya melalui pendidikan gizi.

\section{DAFTAR PUSTAKA}

Akib, A., \& Sumarmi, S. (2017). Kebiasaan Makan Remaja Putri yang Berhubungan dengan Anemia : Kajian Positive Deviance. Amerta Nutrition, 1(2), 105. https://doi.org/10.20473/amnt.v1i2.2017. 105-116

Chen, M.-H., Su, T.-P., Chen, Y.-S., Hsu, J.-W., Huang, K.-L., Chang, W.-H., ... Bai, Y.-M. (2013). Association between psychiatric disorders and iron deficiency anemia among children and adolescents: a nationwide population-based study. BMC Psychiatry, 13(1), 161. https://doi.org/10.1186/1471-244X-13-161

IDAI. (2013). Nutrisi pada remaja. Retrieved from http://www.idai.or.id/ artikel/seputar-kesehatan-anak/nutrisipada-remaja

Kaur, S., \& Sangha, J. K. (2016). Effect of iron supplementation along with vitamin $\mathrm{C}$ and nutrition counselling on the anaemic status of adolescent girls. International Journal of Health Sciences and Research, 6(5), 279-287.

Kooshki, A., Mohammadi, M., \& Rivandi, M. (2018). Nutritional intake and its association with educational achievement in high-school students in Islamic Republic of Iran. Eastern Mediterranean Health Journal, 24(6), $532-537$. http s: // d o i.org / 10.26719/2018.24.6.532

Nurmasyita, N., Widjanarko, B., \& Margawati, A. (2016). Pengaruh intervensi pendidikan gizi terhadap peningkatan pengetahuan gizi, perubahan asupan zat 
gizi dan indeks massa tubuh remaja kelebihan berat badan. Jurnal Gizi Indonesia (The Indonesian Journal of

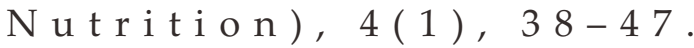
https://doi.org/https://doi.org/10.14710/j gi.4.1.38-47

Paracha, P. I., Bakht, S., Paracha, S. I., Vriesekoop, F., Alam, I., Din, Z. ud, \& Ullah, N. (2016). Nutritional status, dietary practices and physical activities of adolescents in public and private schools of Karachi, Pakistan. Obesity Research Open Journa 1, 3 (2), 30-39. https://doi.org/10.17140/OROJ-3-125

SPRING. (2017). Micronutrient deficiencies. In Understanding anemia: Guidance for conducting a landscape analysis (2nd Editio). Arlington, VA: Strengthening Partnerships, Results, and Innovations in Nutrition Globally (SPRING) project. Retrieved from https://www.springnutrition.org/publications/series/underst a n d i n g - a n e m i a / c a u s e s anemia/micronutrient-deficiencies

Suryani, D., Hafiani, R., \& Junita, R. (2017). Analisis pola makan dan anemia gizi pada remaja putri Kota Bengkulu. Jurnal Kesehatan Masyarakat Andalas, 10(1), 11. https://doi.org/10.24893/jkma.v10i1.157

Tayel, D. I., \& Ezzat, S. (2015). Anemia and its associated factors among adolescents in
Alexandria, Egypt. International Journal of Health Sciences and Research, 5(10), 260-271.

WHO. (2018a). Adolescent health. Retrieved March 8, 2018, from http://www.who.int/ topics/adolescent_health/en/

WHO. (2018b). Anaemia. Retrieved March 6, 2018, from http://www.who.int/ topics/anaemia/en/

World Health Organization. (2011). Haemoglobin concentrations for the diagnosis of anaemia and assessment of s e ve rity. Re trieved from https://apps.who.int/iris/handle/10665/8 5839

Purna, N., Reni, Z. (2016). Vitamin C pada Pisang Ambon (Musa paradisiaca S.) dan Anemia Defisiensi Besi. Medical Jounal of Lampung University, 5(4), 124-127. https://juke.kedokteran.unila.ac.id/index .php/majority/article/view/897

Reka, A., Widajanti, L., Nugraheni, S. (2016). Hubungan Asupan Zat Besi, Asam Folat, Vitamin B12 Dan Vitamin C Dengan Kadar Hemoglobin Siswa Di SMP Negeri 2 Tawangharjo Kabupaten Grobogan. Jurnal Kesehatan Masyarakat (e-Journal), 4 ( 4 ), $521-528$. https://ejournal3.undip.ac.id/index.php/j $\mathrm{km} /$ article/view/14282 